\title{
A World Ethos for Humanistic Management: Love Story or Dialogue Platform?
}

\author{
Jonathan Keir ${ }^{1,2}$ (D)
}

Received: 19 February 2017 / Accepted: 25 July 2017 / Published online: 2 August 2017

(C) Springer International Publishing AG 2017

\begin{abstract}
Humanistic reform of management theory and practice could be expected to take a plurality of guises. One such manifestation of the desire for a humanistic reorientation of management discourse is the Weltethos Institut at the University of Tübingen, Germany. The Institute's work builds on the legacy of founder Hans Küng in the sphere of interreligious and intercultural dialogue, and seeks to apply the humanistic insights learnt there to the world of organisations. For Küng, the 'World Ethos' (Weltethos) is a discovery, less of a common letter than of a common spirit among the world's major and minor spiritual and cultural traditions, which he summarises as 'Basic Trust in life and reality' (in German Grundvertrauen or Lebensvertrauen), a yes-saying disposition of love for life 'despite all temptations to reject it'. Without such a basic disposition, Küng argues, 'no one can behave ethically'. This paper explores the paradox at the heart of the 'World Ethos' idea as it applies to questions of organisational leadership and management: if a certain spirit of Grundvertrauen among employees is indeed a feature of successful organisations, the attempt to cultivate it directly in the name of increased efficiency or profit is a potentially sinister and counter-productive enterprise. A more truly humanistic approach to organisational management might ease up on the top-down 'love and trust' message and instead provide a platform on which all members of an organisation feel free to reveal their 'whole selves' and explore their own spiritual sources - and those of colleagues - in a critical but ultimately trusting and constructive climate.
\end{abstract}

Keywords Humanistic management · World Ethos (Weltethos) · Basic Trust (Grundvertrauen/Lebensvertrauen) · Hans Küng

Jonathan Keir

keir@weltethos-institut.org; keirj@ksfn.de

1 Weltethos Institut, University of Tübingen, Tübingen, Germany

2 Karl Schlecht Foundation, Aichtal, Germany 


\section{Introduction}

Humanistic reform of management theory and practice could be expected to take a plurality of guises. One such manifestation of the desire for a humanistic reorientation of management discourse is the Weltethos Institut at the University of Tübingen, Germany (est. 2012). The Institute's work builds on the legacy of founder Hans Küng in the sphere of interreligious and intercultural dialogue and seeks to apply the humanistic insights learnt there to the world of organisations. For Küng, the 'World Ethos' (Weltethos) is a discovery, less of a common letter than of a common spirit among the world's major and minor spiritual and cultural traditions, which he summarises as 'Basic Trust in life and reality' (Grundvertrauen or Lebensvertrauen), a yes-saying disposition of love for life 'despite all temptations to reject it'. Without such a basic disposition, Küng argues, 'no one can behave ethically’ (Küng 2002: 21).

On this account, then, the primary challenge of humanistic management would appear to be to foster such basic love and trust within the individuals who comprise organisations. One could seek to implement this ambitious agenda in an almost limitless number of ways; some may achieve success, others may not, while still others may prove to be actively counterproductive. A top-down 'love-blitz' seems highly likely to foster derision and resentment among junior staff; talking about trust without embodying it is as useless as trying to promote love without feeling it. One may maintain the lofty 'World Ethos' managerial goal of more Grundvertrauen in an organisation, but this may require above all else extreme flexibility, exemplary openness and self-deprecating humour from managers themselves.

This paper explores the paradox at the heart of the 'World Ethos' idea as it applies to questions of organisational leadership and management: if a certain spirit of Grundvertrauen among employees is indeed cultivated by successful organisations, the attempt to cultivate it directly in the name of increased efficiency or profit is a potentially sinister and counterproductive enterprise. A more truly humanistic approach to organisational management might ease up on the top-down 'love and trust' message and instead provide a platform on which members feel free to reveal their 'whole selves' (Hallowell et al. 2008) and to explore their own spiritual sources - and those of colleagues - in a climate of critical but ultimately trusting and constructive exchange. The early experiences of the Weltethos Institut, both in its in-house teaching and its relationship with its chief donor, the Karl Schlecht Foundation (established by Putzmeister concrete-pump mogul Karl Schlecht), will serve less as formal case studies - the whole point of humanistic management is that it is free to operate outside the experimental paradigms imported from the natural and social sciences - than as catalysts for further reflection on the meaning and value of the 'World Ethos' idea.

\section{Teaching the World Ethos: Lessons from the Weltethos Institut}

Students from across the University of Tübingen typically react to their first contact with the Weltethos Institut with disbelief that they are finally, in the course of often heavily vocational studies, being asked for their own opinions and given the freedom to explore topics largely of their own choice. This does not mean a lack of discipline in the allocation of compulsory reading material, but it does open up a qualitative space in which what matters above all is the courage to think freely and critically for oneself about what one has read, even if that means being forced to confront an unfavourable image of oneself or one's own past behaviour in the process. As Hans Küng himself has repeatedly stressed (Küng 2002, 2010, 2013), 
Grundvertrauen cannot be cultivated by avoiding the harsh realities of human life: death, sickness, greed and so on. The only way meaningfully to build Basic Trust is to face these problems squarely, armed with the goodwill of one's teachers and classmates, all in the hope that, along the way, a belief in something beyond oneself - in Küng's formulation, a 'Yes' to life and reality as such - might somehow be cultivated. Such Grundvertrauen represents, if somehow miraculously won in the process of 'education', a veritable 'leading out' from the prison of animal, essentially consumerist selfhood into a world where higher humanistic values are real.

Outcome-driven logics of all kinds, however-from homo economicus-based models in business school curricula to profit targets and impact indicators in the graduate office-act essentially to sabotage this entire enterprise. It is an utter perversion of the values of love and trust in the first place - and therefore, by extension, of the 'World Ethos' idea as a whole - to insinuate that the incorporation of such values into organisational structures will allow firms to increase profits or otherwise improve 'outcomes'. A positive correlation between levels of Grundvertrauen and profit may or may not be proven true-one hopes that it at least sometimes might be, and we already see indirect evidence that it sometimes is (von Kimakowitz et al. 2011) — but this entirely misses the point of what Grundvertrauen is for in the first place: it is the end, not the means of human fulfilment. Firms need to make some form of profit in order to survive, but there are worse things than failing to do so and being forced to close down: a loss of Grundvertrauen among the individuals comprising the firm would, if we are serious about our humanism, surely be much worse.

The task of persuading management professionals to adopt such a humanistic ethos is tantamount to a Copernican shift away from material outcomes and towards an embrace of the value of trust for its own sake. Actually saying so, however, to an entire community which regards its commitment to measurable outcomes as a sign of adult realism and responsibilitya badge of honour rather than a cause for potential shame - is fraught with danger, perhaps not physical danger to the person doing so but at least the risk of being shown the door before one has a foot inside it. If the goal of the Humanistic Management Network is to reach, among others, Goldman Sachs with its message, then one is forced to adopt strategies which will at least be appealing enough to win a first hearing in such circles. This may require diplomacy and compromise; finding the right language for such cohorts is an ongoing challenge for the Weltethos Institut as it seeks to win credibility without succumbing to the same outcomedriven logics of profit and organisational 'impact' that it is trying to combat. While no one ever makes up her mind on Basic Trust once and for all—Küng's demanding ecumenical theology requires a constant renewal of Lebensvertrauen in the face of ever-shifting pressures to abandon it - there is certainly far more which can be done with students of business and other university disciplines in their late teens and early twenties than with CEOs and wizened senior veterans of non-humanistic, mainstream business culture: even to attempt to enter such high offices with a 'hippy' message of love and trust - particularly when one offers academic theological arguments rather than coal-face tales of increased profits - is to invite (in no particular order) ridicule and hostility.

There is nothing 'hippy' or flippant or New Age, however, about the World Ethos idea; on the contrary, it is a deep thesis about the true nature of our civilisational inheritance, a wisdom involving the heart as well as the head, the result of an engagement with history for its own sake, or rather for the sake of something beyond oneself, not a pit-mine from which nuggets of self-help advice can lazily and greedily be gleaned. Those who are lucky enough to study the world's religious, spiritual and cultural traditions in early life - 'the best that has been thought 
and said in the world' in Matthew Arnold's immortal phrase (Arnold 1869) — gain strength from doing so, a strength of character which will allow them to cope with the responsibilities of organisational leadership and to make decisions in these positions which are ethical as well as prudent. It would be a mistake either to underestimate or to overestimate how much firms can do for the character education of their employees with individuals once they arrive at a firm or have been active there for many years; it is not unreasonable, however, for a university institute like the Weltethos Institut to concentrate on students. This is not to say that public dialogue and engagement with the business community are not needed, both for their own sakes and for strategic reasons; it is simply to restate what is 'humanistic' about the idea of 'Humanistic Management' in the first place, namely, on Küng's account, a transmission of Grundvertrauen-promoting civilisational wisdom from one human generation to the next.

The Weltethos Institut finds itself in the unique position of having simultaneously to navigate the interests of the University of Tübingen administration and those of donor, concrete-pump mogul and philosophy autodidact Karl Schlecht, who takes a more proseltytising approach to the World Ethos idea — not in the sense that he believes it is a new world religion (like Küng, he is quick to dismiss such an unappealing vision), but at least in the sense that he sees Weltethos as a concrete idea with the ability to motivate people everywhere to become better leaders. This is not exactly a 'research agenda' fit for a typical twenty-first-century university, even if it fits to some extent into an older, more humanistic and character-based idea of higher education. Schlecht himself discovered the importance of character and a disposition of Grundvertrauen among managers in the course of half a century in charge of the industrial empire Putzmeister; the promotion of this Basic Trust among the business leaders of today and tomorrow is now one of the central goals of the Karl Schlecht Foundation. The problem, however, is that Schlecht has never studied business or management at university, and has very little idea what might be required to make the 'World Ethos' idea palatable in a contemporary business school context. While Schlecht himself is admirably convinced that Grundvertrauen, as described by Hans Küng and his other 'biophilic' North Star Erich Fromm in The Art of Loving (Fromm 1956), is a condition for long-term success in business (and notoriously seizes every public and private opportunity to say so), simply telling people that they must love and trust is counterproductive and pointless: Grundvertrauen is not an idea to be patented, marketed and sold like a concrete pump, nor is it an idea which the logic of science can, like a cure for cancer, research, package and mass retail. The difference between the humanities and the sciences (including the social sciences) is one of direct experience and description, on the one hand, and indirect experience and explanation, on the other: we may conduct observational experiments in order to develop evidence-based scientific theories which explain the world around us and help us to develop new technologies, but humanistic 'knowledge' or 'wisdom' - even the 'practical wisdom' currently so in vogue in academic management circles (e.g. Malloch 2014) - is always an individual experience or set of experiences gained in direct contact with human beings and their cultural products. The best we can do as a humanistic institute is intimately to introduce and describe these products to individual students (Scruton 2013), exchanging and discussing our experiences with them, rather than offering emotionally neutral, scientific explanations of everything. Science can, and frequently does, enrich the humanistic exchange, but it cannot and should not replace it.

One successful leadership seminar run at the Weltethos Institut by Prof. Hans-Wolf Sievert, for example, asks students to watch the classic 1957 Sidney Lumet film Twelve Angry Men (Lumet and Rose 1957) together and to discuss the implications of the film for good leadership. There are no a priori right answers to this question; all we can say is that the film 
forces us to confront a situation in which the self-interest of twelve jurors runs directly counter to the putatively higher ethical good of due legal process; all but one of the men are keen to get what looks like an open-and-shut guilty verdict out of the way as quickly as possible and return to their private lives. One by one, the jurors are forced to admit to themselves that there might be more to the case than meets the eye; eventually, after several of the jurors have been made to confront their own personal demons and discovered a fragile but ultimately intact Grundvertrauen, a unanimous not-guilty verdict is reached on the basis of a fair assessment of the evidence and uninhibited by the psychological complexes and self-absorptions of the jurors. One man, Davis (played by Henry Fonda), sets the ball rolling simply by having the courage to trust in the process and the outcome, whatever they may be, and to seek the truth of the matter in the interests of the accused; the gesture on the steps of the courthouse by a fellow juror (McCardle) simply to ask Davis his name before the two head their separate ways following the not-guilty verdict is in every sense its own reward for the moral leadership which Davis shows.

No two students will experience Twelve Angry Men in the same way, and no one is suggesting that students should be tested to check that they have drawn the specific moral messages from it that the instructor may have had in mind, but only such experiences, and the chance to discuss them openly with peers and teachers who have shared the same experiences, can hope to mitigate the cumulative deleterious impact on character of thousands of hours spent internalising homo economicus-based profit-maximisation models (Dierksmeier 2016a) in the course of university studies and later in the workplace.

\section{So, Love Story or Dialogue Platform? What is the 'World Ethos?'}

Humanistically speaking, there is more 'ethos' to be recovered in Casablanca and Lalaland, and in critical discussions of them, than in the well-intentioned United Nations Principles for Responsible Management Education and other similar, dishwater-dull CSR-style lists of values and other mainstream 'business ethics' initiatives. In one sense, the humble goal of the humanistic management training offered by the Weltethos Institut is to offer students access, via contact with 'the best that has been thought and said in the world', to hidden parts of themselves, corners of the heart where the still audible voice of Grundvertrauen might be heard; no one-page list of values, however elegantly or democratically formulated, can hope to compete with literature, music, sculpture or the other highest forms of human expression in this endeavour. University age is far too late to implant Basic Trust and love for life in the hearts of those who have never known them in their family environments (Küng 2010); it is not, however, too late to build on whatever stores of Lebensvertrauen are lying untapped beneath the surface. Logos and slogans featuring the word Grundvertrauen or 'I love Weltethos' are certainly not the way to go about this, both because they risk converting the World Ethos movement into a perceived cult, and because they miss the point of what Grundvertrauen is, namely something one discovers, if at all, for oneself in the intimacy of one's contact with the world and in dialogue, sometimes difficult, with other human beings. The idea of wanting to share this store of goodness, once discovered in oneself, with others is entirely natural and healthy, but the logic is neither that of the social scientist trying to defend her theory nor that of the entrepreneur trying to sell you her product nor, for that matter, that of the religious zealot trying to convert you to her religion; it is a humanistic gift only transferable by shared experience and conversation. Such a process takes time. Not all the hours of one's 
education can possibly be devoted to this task; it is not unreasonable for universities to wish to train doctors, lawyers, engineers and even managers who are capable of dealing with the complex theoretical and factual realities of twenty-first-century globalisation. A healthy balance, however, must surely be struck between vocational training and humanistic enrichment; to view such enrichment as a luxury is not only to risk cultural, political, and ultimately even purely economic suicide, but above all to reveal ourselves as having in all likelihood been deprived of these higher experiences in our own educations. The arguments for a humanistic turn in management education rest on subjective experiences, not objective facts, even if we might sometimes be able to engineer and summon facts to support them if reluctantly forced to do so. Like Louis Armstrong when asked to define what jazz was, defenders of humanistic management education could do worse than to reply to sceptics and critics with some version or other of Armstrong's own famous words: 'If you have to ask, you'll never know.' The Grundvertrauen at the heart of the World Ethos idea is just such an experience; no amount of my telling you that I have it will cause you to have it, though I may be able to share stories with you that reach you somehow. I won't know in advance which ones they might be, but the dialogical attempt is surely worth it for its own sake.

Such uplifiting stuff may inspire a student audience, but can the Weltethos Institut really be expected to be taken seriously if it goes out to grown-up companies with this message, or invites them to hear it? The consensus view would seem to be that such preaching from humanistic Neptune is best avoided, at least in the first instance; the most constructive thing we can provide is a friendly but neutral platform for business leaders to talk to each other about values after long days or weeks at the office, where such frank conversations may for a variety of organisational and cultural reasons be less likely to take place. I divulge no secret by saying that Weltethos Institut donor Karl Schlecht would prefer to see more active proselytising of the 'World Ethos message' at such events, and his criticisms are perhaps partially justified; the idea of a World Ethos for business will one day need to be more than the polite evening exchange of trade stories. The World Ethos, indeed, lives in individuals and their stores of Grundvertrauen; recovering the sources of Basic Trust in individuals requires a much deeper and more intimate human dialogue than public discussions of 'profit with principles' and 'smarter business' typically allow.

The need for such humanistic exchange remains even in an otherwise perfect society, because it is more than a means to an end: the cultivation of Grundvertrauen, Küng argues, is an end in itself. The urgency of sensible, pragmatic and ethical reform in a host of policy areas, from financial regulation to taxation and environmental management, ought not to obscure the prior, essentially cultural agenda of the Humanistic Management enterprise; collateral utilitarian benefits aside, the 'character of the manager' (Beabout 2013) is worth cultivating for its own sake. What Saudi reformer Ibrahim al-Buleihi calls 'the genius of automatic attention'the spontaneous interest in a given subject or challenge as opposed to externally coerced attention to a problem - may have given rise to the Renaissance, Enlightenment and many of the creative products of modern industry which required an 'exceptional effort' to conceive and produce (al-Buleihi 2016), but such a state of attention is itself, based as it is in the Grundvertrauen which makes it possible, already the goal of management education, regardless of the fruits which flow from it. Paradoxically, excessive concern for outcomes reflects a lack of Grundvertrauen and, by extension, an absence of the 'World Ethos'; immersion in the challenge is the goal. Profit is simply the means necessary to sustain this 'exceptional effort', an effort made possible by 'automatic attention' rooted in a Basic Trust in life which is itself the highest form of human self-realisation. Collaterally, though only collaterally, such 
exceptional effort and sustained attention is typically required to produce practical ideas of lasting value, in business as in other spheres of human activity. This holistic, humanistic vision of human motivation, including managerial motivation, also lies behind the Japanese idea of kaizen (Maurer 2012) before its contact with Western modernity; to admire Toyota and other kaizen-inspired Japanese firms for their profit-generating prowess is to put the cart before the horse, and to fail to embrace the philosophy of kaizen, its attention to detail and striving for continual improvement, for its own sake.

\section{Concluding Remarks}

The 'World Ethos' is a love story, to be sure - or rather, building on Hans Küng's original formulation, the collective outcome of loving and trusting individual relationships with life itself — but if we didn't talk about it with each other and share experiences with each other and pass down the flame of civilisation from one generation to the next, we could never hope to reach such a state of Basic Trust in life on our own. In a global business culture singularly committed to outcomes and terrified of failure - not for its own sake but for the material costs of that failurethe only way to free students and practitioners of management from the tyranny of this fear is to offer lived experiences of 'the best that has been thought and said in the world'. This involves deep, humanistic engagement, not post hoc, self-help-bestseller-style approaches to 'successful, profit-increasing leadership'. Such engagement, however, requires precisely that one meet people on their own turf; preaching 'love' and 'trust' and 'intrinsic motivation' to management students or actual managers in overly hippyish or didactic language is unlikely to succeed, and highly likely to backfire. Giving students of economics and business a chance to ask their own questions about the means and ends of business, however, and ensuring that students of these disciplines are not deprived of the humanistic education which is the shared right of all, is the common goal of both the University of Tübingen's Weltethos Institut and of the Humanistic Management Network. The idea of a 'World Ethos' for global business - something much deeper than outward CSR-style agreement on lowest-common-denominator ethical principles within an otherwise amoral and underregulated global economic system - is worth celebrating, defending and promoting, not only because of the negative externalities caused by this gap between behaviour and policing, but first and foremost because of the liberating effects on the individual of the Grundvertrauen or Basic Trust in life and reality on which it is based. This is the essence of the 'qualitative freedom' paradigm shift sought by Humanistic Management and 'World Ethos' pioneer Claus Dierksmeier in economics and related disciplines (Dierksmeier 2016a, b). The efficient allocation of scarce material resources and the deployment of the human creativity which combats and reduces such scarcity are useful means, to be sure, but the end of management is elsewhere, in the ether so to speak, or rather in the 'ethos', in the humanistic spirit of creativity itself.

\section{References}

al-Buleihi, Ibrahim. 2016. 'Abqariyyat ul-Ihtimam il-Tilqa'iyy (The Genius of Automatic Attention). Tunis: AlTanwir.

Arnold, Matthew. 2009 (1869). Culture and anarchy. Oxford: Oxford University Press.

Beabout, Gergory R. 2013. The character of the manager: from office executive to wise steward. Basingstoke: Palgrave Macmillan. 
Dierksmeier, Claus. 2016a. Reframing economic ethics: the philosophical foundations of humanistic management. New York: Palgrave.

Dierksmeier, Claus. 2016b. Qualitative Freiheit: Selbstbestimmung in weltbürgerlicher Verantwortung. Bielefeld: Transcript.

Fromm, Erich. 1995 (1956). Die Kunst des Liebens (The Art of Loving). München: dtv.

Hallowell, Edward M., et al. 2008. Harvard Business School review on bringing your whole self to work. Brighton: Harvard Business School Press.

Küng, Hans. 2002. Wozu Weltethos? Religion und Ethik in Zeiten der Globalisierung (Whither the World Ethos? Religion and Ethics in Times of Globalisation). Freiburg: Herder.

Küng, Hans. 2010. Was ich glaube (What I Believe). München: Piper.

Küng, Hans. 2013. Was bleibt (What Remains). München: Piper.

Lumet, Sidney, and Reginald Rose. 1957. Twelve angry men. Los Angeles: Orion-Nova Productions.

Malloch, Theodore Roosevelt. 2014. Practical wisdom in management: business across spiritual traditions. Abingdon-on-Thames: Routledge (Greenleaf).

Maurer, Robert. 2012. The spirit of Kaizen: creating lasting excellence one step at a time. London: McGraw-Hill.

Scruton, Roger. 2013. Scientism in the arts and humanities. http://www.thenewatlantis.com/publications/scientism-inthe-arts-and-humanities. Accessed 26 Dec 2016.

von Kimakowitz, Ernst, et al. 2011. Humanistic management in practice. Basingstoke: Palgrave Macmillan. 